\title{
Help or Hindrance? Causal Ambiguity and Supplier Involvement in New Product Development Teams*
}

\author{
Antony Potter and Benn Lawson
}

Suppliers are increasingly being involved in interorganizational new product development (NPD) teams. Successful management of this involvement is critical both to the performance of the new product and to meeting the project's goals. Yet the transfer of knowledge between buyer and supplier may be subject to varying degrees of causal ambiguity, potentially limiting the effect of supplier involvement on performance. Understanding the dynamics of causal ambiguity within interorganizational product development is thus an important unanswered empirical question. A theoretical model is developed exploring the effect of supplier involvement practices (supplier involvement orientation, relationship commitment, and involvement depth) on the level of causal ambiguity experienced within interorganizational NPD teams, and the subsequent impact on time to competitor imitation, new product advantage, and project performance. The model also serves as a test of the paradox that causal ambiguity both inhibits imitation by competitors, but adversely affects organizational outcomes. Survey data collected from 119 research and development-intensive manufacturing firms in the United Kingdom largely support these hypotheses. Results from structural equation modeling show that supplier involvement orientation and long-term relationship commitment lower causal ambiguity within interorganizational NPD teams. The results also shed light on the causal ambiguity paradox showing that causal ambiguity during interorganizational NPD decreases both product and project performance, but has no significant effect on time to competitor imitation. Instead, competitor imitation is delayed by the extent to which the firm develops a new product advantage within the market. A product development strategy based upon maintaining interfirm causal ambiguity to delay competitor imitation is thus unlikely to result in a sustainable competitive advantage. Instead, managers are encouraged to undertake supplier involvement practices aimed at minimizing the level of knowledge ambiguity in the NPD project, and in doing so, improve product and project-related performance.

\section{Introduction}

A s firms extend their new product development (NPD) activities across organizational boundaries, greater attention is being given to suppliers and their role within interorganizational NPD teams (Clark and Fujimoto, 1991; Song and Di Benedetto, 2008; Wynstra, von Corswant, and Wetzels, 2010). This involvement can range from consultations on product design ideas to allowing suppliers to take responsibility for a number of NPD processes. Successful management of the process is critical both to the performance of the new product and the future survival of the firm, with benefits including improved product quality, functionality, manufacturability, reduced development times, access to supplier technology, and lower project costs (Bstieler

Address correspondence to: Antony Potter, Manchester Business School, University of Manchester, Manchester M15 6PB, UK. E-mail: antony.potter@mbs.ac.uk. Tel.: +44 (0)1612756466.

* This research was funded by a grant from the Engineering and Physical Sciences Research Council, UK (Grant Number: EP/E003990/1). and Hemmert, 2010; Petersen, Handfield, and Ragatz, 2003; Ragatz, Handfield, and Scannell, 1997). A number of studies have, however, also found mixed or negative effects on new product performance (King and Penleskey, 1992; Wagner and Hoegl, 2006). Consequently, one of the key challenges in the product innovation literature is to understand the theoretical rationale that explains why and how supplier involvement leads to improved organizational performance (Johnsen, 2009).

Causal ambiguity, defined as "a basic ambiguity concerning the nature of the causal connections between actions and results" (Lippman and Rumelt, 1982, p. 418), is frequently proposed as an explanation for variation in organizational performance (Ambrosini and Bowman, 2010; King, 2007; Lippman and Rumelt, 1982; Reed and DeFillippi, 1990). At the product development level, project team members often face considerable difficulty in articulating the precise nature of relationships among knowledge, technologies, and outcomes both within the project itself, and in the integration of supplier's knowledge and technologies (Bstieler and Hemmert, 2010). However, comparatively few studies have empirically 
assessed causal ambiguity within the context of interorganizational NPD. It remains unclear which supplier involvement practices reduce the prevalence of causal ambiguity, and influence its subsequent effect on product development outcomes. King and Zeithaml (2001) also argue that an unresolved causal ambiguity paradox exists, namely that although causal ambiguity limits competitor imitation and sustains competitive advantage, at the same time it also impedes the transfer and leverage of internal capabilities, adversely affecting firm performance (King, 2007; Pich, Loch, and De Meyer, 2002). Understanding the dynamics of causal ambiguity within interorganizational product development is an important unanswered empirical question.

A resource-based perspective is adopted to explore the relationships among supplier involvement practices, causal ambiguity, and product development outcomes (Barney, 1991). In doing so, a number of contributions to the product innovation literature are made. First, the study extends the literature on causal ambiguity to the context of inteorganizational NPD teams. Mosakowski (1997, p. 414) argues that "the full implications of this concept have largely been undeveloped," and our study examines sources of intrafirm and interfirm ambiguity to provide insight into its role during NPD (King, 2007). Second, supplier involvement activities are investigated, such as involvement orientation, the depth of involvement, and long-term commitment, which may reduce the level of causal ambiguity reported within interorganizational NPD teams. Third, the causal ambiguity paradox (King and Zeithaml, 2001) is examined in a NPD context, arguing that while causal ambiguity can delay time to competitor imitation, it will also constrain the ability of internal managers to effectively manage product and project-related performance (Pich et al., 2002; Powell, Lovallo, and Caringal, 2006).

\section{BIOGRAPHICAL SKETCHES}

Dr. Antony Potter is a lecturer in operations management at Manchester Business School, University of Manchester. He received a Ph.D. from the University of Sheffield. His research interests focus on supplier involvement in new product development, supply chain risk, and the evolution of clusters and networks. He has published in Journal of Economic Geography, Regional Studies, and International Journal of Operations and Production Management.

Dr. Benn Lawson is a senior lecturer in operations management at Cambridge Judge Business School, University of Cambridge, UK. He received his Ph.D. from The University of Melbourne. His research interests are in the areas of new product development and supply chain management, and he has published on these topics in Journal of Product Innovation Management, Journal of Operations Management, Journal of Supply Chain Management, and Research Technology Management.
The theoretical framework explores the relationships among supplier involvement practices (involvement orientation, involvement depth, and long-term commitment), causal ambiguity, and performance in terms of competitor imitation, new product advantage, and project performance. The remainder of the article proceeds as follows. First, the literature on supplier involvement and causal ambiguity are reviewed, before hypotheses are developed to build the theoretical model. The research design adopted is then described, followed by discussion of results arising from the structural model. The final section examines the managerial implications of the findings, before the conclusions, limitations, and directions for future research are explored.

\section{Literature Review}

\section{Supplier Involvement in NPD}

In their seminal analysis of the different approaches used by Japanese, American, and European automotive firms to develop new products, Clark and Fujimoto (1991) identified that the success of Japanese new products was, in part, attributable to the way they involved suppliers in NPD. Inspired by the success of leading Japanese automotive firms that pioneered the practice, firms within many different industries and countries have turned increasingly to supplier involvement (Liker, Kamath, Wasti, and Nagamachi, 1996; Wasti and Liker, 1997; Wynstra et al., 2010). Current best practice highlights the importance of practices such as greater supplier responsibility, involvement orientation, supplier team membership, involvement depth, cross-functional integration, employee training, trust, long-term commitment, and intensive interorganizational knowledge sharing and communication (Athaide and Klink, 2009; Bstieler, 2006; Lau, Tang, and Yam, 2010; Lawson, Petersen, Cousins, and Handfield, 2009; Petersen, Handfield, and Ragatz, 2005; Ragatz et al., 1997). Three of these practices, namely, buyer's orientation to supplier involvement, involvement depth in NPD, and long-term relationship commitment are examined.

Strategic alignment of the firm and its supplier is an important prerequisite for achieving superior performance when suppliers are involved in NPD (Echtelt, Wynstra, Weele, and Duysters, 2008; Spanjol, Qualls, and Rosa, 2011). One of the most effective ways of achieving strategic alignment is to formalize an involvement orientation within the firm by outlining clearly the technology road map, development path, organizational routines, and management controls that the firm will use 
to involve the supplier. Following Chen and Paulraj (2004), supplier involvement orientation is defined as the extent to which the firm has developed an orientation toward involving suppliers in crucial project and planning processes within the NPD project.

Suppliers are often a vital source of innovative knowledge, providing creative ideas, prototype designs, product modifications, and technologies which the firm can integrate into their own new product (von Hippel, 1988). Involving suppliers early and extensively in NPD projects is one means of capturing these benefits (von Hippel, 1994). Involvement depth is defined as the extent to which suppliers are involved in different stages of the NPD cycle, such as concept development, product design, prototyping, and preproduction (Jayaram, 2008; Song and Di Benedetto, 2008). Lawson et al. (2009), for example, found that greater supplier involvement depth enables the firm to access a wealth of technical knowledge that facilitates joint problem solving within the interorganizational NPD team.

One of the ways to successfully involve suppliers is for the firm and the supplier to develop long-term relationship commitment (Dyer and Ouchi, 1993; Sako, 1992). Building on Paulraj, Lado, and Chen (2008), long-term commitment is defined as the firm's intention to maintain a long-term relationship with the supplier they have involved into their NPD project. The "shadow of the future" (Parkhe, 1993) cast by the long-term commitment, in this sense, encourages the partners to focus on developing knowledge-sharing routines and relational bonds, which may ultimately represent a source of relationship-specific advantage (Dyer and Singh, 1998). Particularly in a NPD context, where knowledge sharing is critical, building strong relationships with suppliers is central to a successful involvement effort.

A large number of empirical studies have found that involving suppliers in NPD can yield significant benefits for the firm along both product and project-related dimensions (e.g., Echtelt et al., 2008; Johnsen, 2009; Lau et al., 2010). Song and Parry (1997), for example, propose new product advantage as the ability of the firm's new product to offer unique features, meet customers' needs, offer higher quality, and provide superior technical performance in comparison with its competitors, and is regarded by many as an important indicator of new product success (Atuahene-Gima and Wei, 2011). On the other hand, project performance is often measured by comparing the performance of a project against the firm's internal goals in terms of quality standards, technical objectives, schedules, budgets, and project goals (Petersen et al., 2003). Additionally, the resource-based view (RBV) has examined the role of knowledge inimitability in maintaining firm advantage, specifically, the time taken for competitors to replicate the performance improvements achieved by the firm's new product (Barney, 1991; McEvily and Chakravarthy, 2002).

However, there are also significant challenges associated with managing interorganizational NPD teams, which can cause many to fail or breakdown completely (Bstieler and Hemmert, 2010). A number of empirical studies have found that suppliers have little influence on performance, with their involvement creating a number of disadvantages for the firm including greater misunderstandings, added project complexity, additional coordination time, increased product development costs, greater supplier switching costs, and lower efficiency (Eisenhardt and Tabrizi, 1995; Hartley, Zirger, and Kamath, 1997; King and Penleskey, 1992). The role of causal ambiguity is a potential explanation of these findings.

\section{Causal Ambiguity during NPD}

Barriers to imitation, particularly those resulting from causal ambiguity, are a central tenet of resource-based theory (Lippman and Rumelt, 1982; Reed and DeFillippi, 1990). Within NPD, causal ambiguity acts a barrier to imitation which can affect the speed with which competitors can imitate the firm's new product performance. In a study of internal stickiness within projects and firms, Szulanski (1996, p. 30) defines causal ambiguity as "ambiguity about what the factors of production are and how they interact during production." Relatedly, Simonin (1999, p. 597) refers to knowledge ambiguity, defined as "a lack of understanding of the logical linkages between actions and outcomes, inputs and outputs, and causes and effects that are related to technological or process knowhow." Both these definitions highlight ambiguity as a cognitive and strategic construct that explains the ability of decision-makers to understand the relationship between a competency and its organizational performance outcomes (King, 2007). This perspective of causal ambiguity is well suited to a product development context, where project outcomes are heavily dependent on the collective understandings developed by the interorganizational NPD team, especially of the knowledge shared between the firm and supplier.

Although early studies tended to focus on the ability of interfirm causal ambiguity to delay imitation by competitors, more recent research has explored the role that intrafirm causal ambiguity plays within the boundaries of the firm (King, 2007; King and Zeithaml, 2001). Rather than causal ambiguity generating a sustainable 
competitive advantage through its ability to impede competitor imitation, this alternative perspective suggests that intrafirm causal ambiguity also restricts factor mobility (Lippman and Rumelt, 1982), diminishes knowledge creation (McEvily and Chakravarthy, 2002), limits knowledge transfer (Simonin, 1999), prevents firms from learning (Huber, 1991), and is associated with poor decision-making (Cording, Christman, and King, 2008). In many cases, when causal ambiguity restricts factor mobility, it limits the ability of managers to leverage the necessary resources that are required to generate a new product advantage (Szulanski, 1996). For example, Reed and DeFillippi (1990, p. 90) argue that "where ambiguity is so great that managers do not understand intra-firm causal relationships, or factor immobility exists, it may be impossible to utilize competencies for advantage." Indeed, McEvily and Chakravarthy (2002) propose that a distinct dilemma exists because whilst causal ambiguity helps to delay competitor imitation, it can also impede the transfer of best practice within the firm, a phenomenon known as internal stickiness (Szulanski, 1996).

\section{Theoretical Framework}

The theoretical framework examines the relationship between supplier involvement practices, causal ambiguity, and performance outcomes within interorganizational NPD projects (Figure 1). Through its ability to foster integrated problem-solving cycles, it is first proposed that supplier involvement practices (involvement orientation, involvement depth, and long-term commitment) have the potential to lower the level of causal ambiguity experienced within the NPD team. The model then tests the causal ambiguity paradox arguing that causal ambiguity extends the time taken for competitors to imitate the firm's new product, but also decreases the extent of new

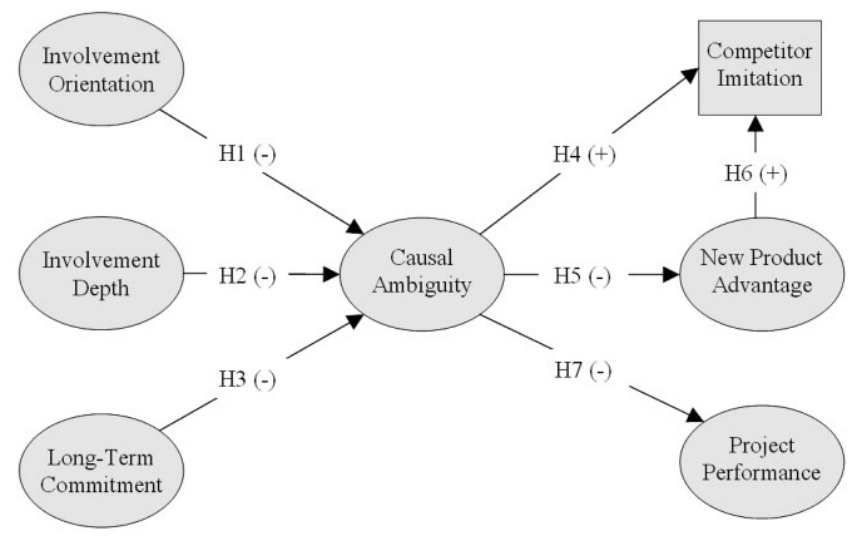

Figure 1. Conceptual Model and Hypotheses product advantage (relative to competitors), and diminishes overall project performance against cost, schedule, and technical objectives.

\section{Supplier Involvement Practices and Causal Ambiguity}

Involving suppliers in a way that minimizes the infusion of ambiguity from the dyadic relationship into the NPD project is regarded as a key management priority (Meyer, 1993; Spanjol et al., 2011). Firms which have a clear orientation to the need for, and management of, suppliers in the NPD project are more likely to achieve reductions in the level of causal ambiguity experienced. For example, development of a supplier involvement methodology prior to commencing the project which specifies, among others, the role, responsibilities, and requirements of the supplier, are more likely to align the supplier's technologies and better understand their interaction with the end product. Further, effective organizational integration requires consensus within the firm and its team members that suppliers are an important part of the NPD process, and that the technological contribution of outside parties are valuable. A firm entering the project with a clear vision and policy regarding the importance, contribution, and management of suppliers is more likely to develop "interconnected problem-solving cycles" (Clark and Fujimoto, 1991), which decreases the uncertainty faced by the project team members, enabling them to diagnose and overcome hurdles to understanding the relevant technological interactions. Based upon this rationale, interorganizational NPD teams will experience lower causal ambiguity when there is greater orientation within the firm toward supplier involvement:

\section{H1: Supplier involvement orientation will lower the degree of causal ambiguity experienced within the interorganizational NPD team.}

Suppliers can also be a vital source of component knowledge to help fill gaps in the NPD team's understanding of a particular technology, and identify design errors and technical flaws in the new product (Rauniar, Doll, Rawskic, and Hong, 2008). They often provide architectural knowledge to help the NPD team learn and understand the causal interactions between the different components, technologies, processes, and systems (Henderson and Clark, 1990). Above all, working closely with suppliers, building joint problem-solving teams, and iterative testing cycles, minimizes the risk of designing a new product or component that is difficult to manufacture and does not take advantage of latest technologies 
(Bstieler and Hemmert, 2010). Bonaccorsi and Lipparini (1994) also highlight benefits in terms of consistency of product tolerances, fewer engineering change orders, greater availability of detailed process data, and early identification of technical problems. Deep integration of suppliers across multiple stages of the development process from concept development, product design, prototyping, and preproduction facilitates opportunities for reducing ambiguity about the characteristics and linkages of valuable resources within the NPD project. Thus, it is proposed that greater depth of supplier involvement across the stages of the NPD cycle will lower the causal ambiguity experienced by interorganizational NPD teams.

H2: Supplier involvement depth will lower the level of causal ambiguity experienced within the interorganizational NPD team.

Commitment to a long-term relationship encourages suppliers to become transparent about areas where there is ambiguity and a lack of understanding within the interorganizational NPD team (Bonaccorsi and Lipparini, 1994; Comer and Zirger, 1997). Over time, the mechanisms through which the firm and the supplier communicate, exchange knowledge, establish goals, and negotiate outcomes will become more clearly defined, limiting ambiguity within the NPD project (Echtelt et al., 2008). The guarantee of a long-term relationship also allows the supplier to invest in the necessary technological capabilities to address any ambiguities the firm may experience during NPD (Sako, 1992). Thus, signaling a long-term commitment to the buyer-supplier relationship can decrease causal ambiguity by tying partners closer to each other, facilitating efficient and effective buyersupplier interactions, reducing incentives for supplier opportunism, and enabling social capital to develop over the project life cycle (Lawson et al., 2009).

H3: Long-term relationship commitment will lower the degree of causal ambiguity experienced within the interorganizational NPD team.

\section{Causal Ambiguity and Performance Outcomes}

Following the tenets of the causal ambiguity paradox, three contrasting performance outcomes are examined: (1) a delay to competitor imitation; (2) a reduced new product advantage; and (3) lower project performance (King, 2007; King and Zeithaml, 2001; Powell et al., 2006). Each relationship is addressed in turn.

A fundamental assumption of RBV theory is that firms can sustain a first mover advantage and temporary monopoly position when they introduce new products into the market that competitors have yet to develop and find difficult to imitate (Barney, 1991; Lieberman and Montgomery, 1988). Without barriers to competitor imitation, a firm can only receive a temporary competitive advantage within the marketplace as competitors can rapidly imitate the new product and capture a second mover advantage (Lieberman and Asaba, 2006; Ordanini, Rubera, and DeFillippi, 2008). Causal ambiguity is recognized as a mechanism which can help delay competitor imitation (Dierickx and Cool, 1989; King and Zeithaml, 2001). When a firm's competitive advantage is derived from resources and routines that are causally ambiguous, there will be a longer imitation lag between when the new product is introduced into the marketplace and when it is imitated by competitors (Reed and DeFillippi, 1990). Causal ambiguity can forestall imitation by increasing the uncertainty about which components are valuable, by raising the costs of discovering the nature of causality, by restricting reverse engineering, and by prolonging the identification of which factors drive superior performance (Lippman and Rumelt, 1982). Thus, it is proposed:

\section{H4: Causal ambiguity within the interorganizational NPD team increases the time taken for competitors to imitate the new product.}

The development of new products is an inherently uncertain, risky, complex, and error-ridden process that often results in suboptimal products containing unforeseen technical glitches (Hoopes and Postrel, 1999; Koufteros, Rawski, and Rupak, 2010; Rauniar et al., 2008). A new product advantage may be diminished when causal ambiguity impedes factor mobility; decreases interorganizational knowledge sharing; limits best practice transfer; fosters internal stickiness within the NPD project; and increases the prevalence of technological mistakes, misunderstandings, and design errors (Hoopes and Postrel, 1999; Simonin, 1999; Szulanski, 1996). Causal ambiguity may also lead managers and scientists within the NPD project to pursue the wrong technological trajectory and target the wrong market segment (Lippman and Rumelt, 1982). Specifically, under conditions of increasing causal ambiguity, the firm will find it difficult to generate a new product advantage, relative to its competitors in the marketplace (Ambrosini and Bowman, 2010; Rijsdijk, Langerak, and Hultink, 2011).

H5: Causal ambiguity within the interorganizational NPD team decreases the level of new product advantage in the marketplace. 
In addition, new product advantage may play an important role in delaying competitor imitation (McNally, Cavusgil, and Calantone, 2010). The literature on competitive imitation suggests that when a new product offers features, unique attributes, higher quality, or enhanced technical performance that are clearly superior in comparison with existing competitor products, this will substantially delay competitor imitation (Lieberman and Montgomery, 1988; Song and Montoya-Weiss, 2001). Furthermore, when suppliers develop technological breakthroughs that are then incorporated into the new product, this relationship-specific resource will prolong the time taken for competitors to imitate the new product. Put simply, the ability of the new product to capture an advantage within the marketplace impedes imitation, copying, and reverse engineering by competitors (McEvily and Chakravarthy, 2002).

H6: The greater the new product advantage achieved by the firm, the longer time it will take for competitors to imitate the new product.

Finally, as Lippman and Rumelt (1982) acknowledge, one of the most important determinants of project performance is the ability of managers to understand the causal factors that contribute to the project's success or failure. Causal ambiguity can decrease project performance by restricting decision-makers' ability to understand the causal connections within the project, thereby increasing the likelihood of project delays, cost overruns, production stoppages, design failures, or compromised technical performance (Pich et al., 2002). Causal ambiguity makes it difficult to identify how individual resources contribute to the project's success because of the complex pattern of interlinked systems, subsystems, technologies, knowledge, and information within the interorganizational NPD project. It can also prevent team members from learning from their past experiences, accessing their stock of knowledge, and improving the project over time (McEvily and Chakravarthy, 2002). Managers may also spend a greater proportion of their time firefighting to prevent systematic project failure (King and Penleskey, 1992; Pich et al., 2002). For example, the team will find it difficult to trace quality defects and glitches within the final product, which can lead to substantial cost and time overruns within the project (Hoopes and Postrel, 1999; Koufteros et al., 2010). Thus,

H7: Causal ambiguity within the interorganizational NPD team decreases the performance of the NPD project.

\section{Research Design}

\section{Sample Characteristics}

A sample of 1700 medium-to-large manufacturing firms was developed from R\&D databases held by Department of Trade \& Industry (UK), and other publicly available sources. Respondents were selected on the basis of their firm's standard industrial classification (top five industries according to R\&D intensity), job function (purchasing manager or equivalent), and plant size (at least 100 employees). R\&D-intensive manufacturing industries within the United Kingdom were the focus of this study, including automotive, aerospace, pharmaceutical, electrical, chemicals, and general manufacturing. These industries were selected due to the likelihood of firms involving suppliers within their NPD activities. To ensure that the firms met the selection criteria, telephone calls were made to each of the manufacturing firms prior to distribution of the survey. This preliminary screening confirmed the difficulties in identifying the most knowledgeable respondent with regards to a supplier's role in a NPD project. Often, several referrals within a firm occurred before the single most knowledgeable respondent could be identified.

After data screening, 204 firms did not meet the selection criteria for the research and were removed, resulting in a final sample of 1496 firms. Ultimately, 160 questionnaires were received, of which seven were unusable due to missing data. The effective response rate is thus $10.3 \%$ (153/1496). Examination of the data revealed that a further 34 responses for a construct in the study, competitor imitation, had not been completed. As competitor imitation is a single-item construct, these responses were removed, leaving a final sample of 119 R\&D-intensive manufacturing firms. Missing value analysis was carried out to test for significant differences between the 34 responses that did not complete the competitor imitation question and the rest of the sample, no significant differences were found.

Of the responding firms, industries represented were electrical $(36 \%)$, aerospace $(16 \%)$, pharmaceutical and medical $(11 \%)$, chemicals $(11 \%)$, and automotive $(9 \%)$. The final $17 \%$ of firms had no response to industry classification. The response by position held within the firm was Operations Manager (19.6\%), R\&D Manager (17.0\%), Purchasing Manager (38.5\%), and Procurement Director $(15.6 \%)$. No significant mean differences were detected between these groups, or across functional departments. The average experience in the industry was 9.56 years, providing support that informants were also 
Table 1. Profile of Respondents

\begin{tabular}{lrr}
\hline & $n$ & Percentage \\
\hline Number of employees & & \\
$<100$ & 39 & 33 \\
$100-500$ & 38 & 32 \\
$500-1000$ & 11 & 9 \\
$>1000$ & 21 & 18 \\
No response & 9 & 8 \\
Total & 119 & 100 \\
Business unit sales volume & & \\
$£ 10$ million-£25 million & 41 & 35 \\
$£ 26$ million-£50 million & 16 & 13 \\
$£ 51$ million-£100 million & 12 & 10 \\
$£ 101$ million-£250 million & 16 & 13 \\
$£ 251$ million-£500 million & 12 & 10 \\
$>£ 500$ million & 17 & 14 \\
No response & 5 & 4 \\
Total & 119 & 100 \\
Industry sector & & \\
Electronics industry & 43 & 36 \\
Aerospace industry & 19 & 16 \\
Pharmaceutical and medical industry & 13 & 11 \\
Chemical industry & 13 & 11 \\
Automotive industry & 11 & 9 \\
Other industries & 20 & 17 \\
No response & 00 \\
Total & 119 & \\
\hline
\end{tabular}

knowledgeable about the issues under investigation. Table 1 presents further sample characteristics.

\section{Survey Administration}

The unit of analysis was a single product development project in which a supplier was involved, and had been completed within the last three years. Respondents were further instructed to select a supplier that had provided a critical component or subassembly into the firm's end product. As an additional validation check, respondents were asked their level of knowledge of the supplier relationship and NPD project. A mean response of 5.8 (out of 7) provides confidence that respondents were knowledgeable regarding the items under investigation.

Ten semi-structured interviews were conducted with purchasing managers, project managers, and design engineers to help develop and refine the focus of the survey. The completed instrument was then pilot-tested with a further 10 managers and 6 expert academics who were asked to critically evaluate and comment on the design, content, clarity, and scaling of the survey. Minor modifications were made based on this feedback. Each respondent was posted a copy of the survey, together with an accompanying cover letter that explained the purpose of the research. A number of procedures were followed in an attempt to enhance the response rate (Dillman, 2000). Respondents had opportunity to respond via return post, or Internet, and were also offered a composite summary of results (Forza, 2002). Also, a reminder postcard was sent to each respondent two weeks after the initial mailing. Finally, a series of follow-up phone calls were made after six weeks in an attempt to elicit response.

\section{Nonresponse Bias}

A number of tests were conducted to detect the presence of response bias. First, we tested for any differences between early and late responders (Armstrong and Overton, 1977). Results indicated no statistically significant differences. Second, sensitivity analysis was conducted to determine whether there were any statistically significant differences between the responses from different managers, with no significant differences identified.

\section{Operationalization of Variables}

All constructs were previously validated and adapted from the extant literature. Items were assessed on a Likert scale ranging from 1 "strongly disagree," to 7 "strongly agree," or 1 "very little" to 7 "a very great extent." A list of all the measures is provided in the Appendix.

Involvement orientation. Chen and Paulraj's (2004) scale was adapted to assess the extent to which the firm had developed a supplier involvement orientation. The scale consisted of four items measuring whether the firm had a formal methodology for involving suppliers, the involvement of key suppliers in product development, the degree of consensus that supplier involvement was needed, and the influence of key suppliers on the development of new products.

Involvement depth. The depth of the involvement of the specific supplier into the NPD project was captured using a measure applied previously by Song and Di Benedetto (2008) and Jayaram (2008), and originally adapted from Stump and Heide (1996). This measure examines involvement depth at different stages of the NPD cycle, including concept development, product design, prototype building and testing, and preproduction.

Long-term commitment. The long-term nature of the relationship between the firm and the supplier was captured using a measure adapted from Paulraj et al. (2008). 
Five key areas that characterize the firm's long-term commitment to the relationship were covered, including whether the firm views the relationship as long-term in nature, is committed to the preservation of the relationship, the extent to which the supplier sees the relationship as a long-term alliance, if the firm expects to be working with the supplier for the foreseeable future, and the significance of the relationship to the firm.

Causal ambiguity. Causal ambiguity incorporates two subfactors (knowledge ambiguity and project ambiguity) based upon Lippman and Rumelt's (1982) original conceptualization, and further work by Simonin (1999) and Szulanski (1996). The subfactor, knowledge ambiguity, asked respondents about the ambiguity of the knowledge transferred from the supplier (Simonin, 1999), including whether the technological know-how held by the supplier was easily transferrable, and whether the association between causes and effects, inputs and outputs was clear. The project ambiguity subfactor assessed the degree of ambiguity present within the NPD project itself (Szulanski, 1996), including the extent to which the project team knew why a given action resulted in a given outcome, how the different technologies within the project interacted to produce the outcome, and, when a problem surfaced within the project whether the precise reasons for failure could be articulated. These items were then reverse scored to reflect the extent of causal ambiguity.

Competitor imitation. The measure of competitor imitation developed by McEvily and Chakravarthy (2002) is used, focusing on the time taken (in months) for major competitors to replicate the performance improvements achieved in the firm's new product.

New product advantage. The existing scale by Song and Parry (1997) is adopted, with respondents asked to assess their firm's new product compared with those of competitors' products in terms of unique features, technical performance, quality, enabling customers to do something they could not presently do, and meeting customers' needs.

Project performance. The measure by Petersen et al. (2003) is used to assess the performance of the NPD project. The five-item construct examined whether, relative to the firm's internal goals, the project had met quality standards, technical objectives, schedule targets, budgeted cost targets and project goals. A 7-point Likert scale anchored at $1=$ "much worse" to $7=$ "much better" was used.
Control variables. A logarithmic transformation of the estimated project length (in months) was used to control for the fact that longer projects will inherently take additional time for competitors to imitate (McEvily and Chakravarthy, 2002). Following the approach of Takeishi (2001), the degree of technological newness of the new product is also coded, as this is likely to have a significant effect on the degree of causal ambiguity experienced, and the extent of advantage gained by the product in the marketplace. Technological newness was set to 1 if a significantly new product design was used, otherwise 0 .

\section{Statistical Analysis}

A two-step process of analysis (Anderson and Gerbing, 1988), with AMOS 7.0 (Arbuckle, 2006), was employed to test the hypotheses. Confirmatory factor analysis (CFA) was adopted to test the construct validity and the unidimensionality of the latent and manifest variables. Table 2 presents the details of the loadings and error terms of the manifest variables onto each latent variable. One of the indicators within each construct was fixed with a value of 1.0 , with a minimum number of three indicators (Jöreskog and Sörbom, 1993). Close attention was given to the modification indices (>3.84), and the data examined for either low factor loadings $(<.40)$ or high residual values (i.e., normalized residuals $>2.58$ ). In addition, inspections were carried out to detect any negative variance or high item correlations, the results of which identified no anomalies. Four items, one each from long-term commitment, new product advantage, project performance, and project-level causal ambiguity were removed due to low factor loadings. No further anomalies were identified from this analysis, and no negative variance and high item correlations were found. One- and two-factor solutions for causal ambiguity were examined, with a chi-square difference test indicating that the second-order factor produced significantly better fit to the data than a one-factor solution $\left(\Delta \chi^{2}(2)=15.86, p<.01\right)$.

Model fit was examined using four different measures: the chi-square test $\left(\chi^{2}\right)$, the comparative fit index (CFI), the Tucker-Lewis Index (TLI), and the root mean square error of the approximation index (RMSEA) (Gerbing and Anderson, 1992). Overall, the results from the CFA are satisfactory $\left[\chi^{2}(273)=409.677, p=.00\right.$; $\mathrm{TLI}=.90 ; \mathrm{CFI}=.92 ; \mathrm{RMSEA}=.065]$. A number of procedures were then followed to check for convergent validity (Bagozzi and Yi, 1988) and discriminant validity (Anderson and Gerbing, 1988; Fornell and Larcker, 
Table 2. Assessment of Reliability and Construct Validity

\begin{tabular}{|c|c|c|c|}
\hline Factors and Items & $\begin{array}{l}\text { Standardized } \\
\text { Loading }\end{array}$ & $\begin{array}{l}\text { Standard } \\
\text { Error }\end{array}$ & $t$-value \\
\hline \multicolumn{4}{|c|}{ Involvement orientation } \\
\hline $\mathrm{O} 1$ & .68 & .19 & 6.09 \\
\hline $\mathrm{O} 2$ & .89 & .16 & 7.11 \\
\hline $\mathrm{O} 3$ & .77 & .16 & 6.66 \\
\hline $\mathrm{O} 4$ & .63 & - & - \\
\hline \multicolumn{4}{|l|}{ Involvement depth } \\
\hline D2 & .56 & .13 & 6.14 \\
\hline D3 & .93 & .16 & 8.14 \\
\hline D4 & .81 & - & - \\
\hline \multicolumn{4}{|c|}{ Long-term commitment } \\
\hline $\mathrm{R} 1$ & .91 & .10 & 11.90 \\
\hline $\mathrm{R} 2$ & .97 & .10 & 12.89 \\
\hline R3 & .88 & .11 & 11.31 \\
\hline $\mathrm{R} 4$ & .79 & - & - \\
\hline \multicolumn{4}{|l|}{ Causal ambiguity } \\
\hline CA1 & .67 & .10 & 6.96 \\
\hline CA2 & .56 & .13 & 5.86 \\
\hline $\mathrm{CA} 3$ & .91 & - & - \\
\hline CA4 & .68 & .16 & 5.79 \\
\hline CA5 & .82 & - & - \\
\hline \multicolumn{4}{|l|}{ Project performance } \\
\hline PP1 & .94 & .19 & 6.56 \\
\hline PP2 & .77 & .14 & 6.28 \\
\hline PP3 & .58 & - & - \\
\hline PP4 & .64 & .15 & 5.57 \\
\hline \multicolumn{4}{|c|}{ New product advantage } \\
\hline PA1 & .86 & .08 & 13.24 \\
\hline PA2 & .90 & - & - \\
\hline PA3 & .74 & .08 & 9.99 \\
\hline PA4 & .89 & .07 & 13.98 \\
\hline
\end{tabular}

1981). The convergent validity of the scales (extent to which the measurement items reflect a common underlying construct) was supported, with estimated coefficients of all indicators being significant $(t>2.0)$.
Average variance extracted (AVE) statistics, measuring the variance captured by the indicators relative to the measurement error, indicate that all the constructs have AVE values greater than the .50 minimum level (Hair, Anderson, Tatham, and Black, 1998). Composite reliability values also provide a further assessment of internal consistency. A minimum value of .70 is recommended as it indicates that around .50 of the variance (the squared loading) can be attributed to the construct of interest (Fornell and Larcker, 1981). The composite reliabilities (CRs), which ranged from .82 to .94 , each met the required level.

All tests of discriminant validity were supportive; in other words, no confidence intervals of the correlations for the constructs ( $\phi$ values) included $1.0(p<.05)$, and the square of the intercorrelations between two constructs, $\phi^{2}$, was less than the AVE estimates of the two constructs (Anderson and Gerbing, 1988). This was true for all pairs of constructs (Fornell and Larcker, 1981). These results suggest the six constructs and their 24 items are reliable and valid in this study. The inter-item correlations, Cronbach's alpha, CR, and AVE values are shown in Table 3.

\section{Empirical Testing of Hypothesized Model}

The structural model was tested using maximum likelihood estimation. Overall, the fit indices reveal that the structural model has a satisfactory model fit $\left[\chi^{2}(307)=470.398, \quad p<.00 ; \quad\right.$ TLI $=.90 ; \quad$ CFI $=.91 ;$ RMSEA $=.067]$. Figure 2 presents the details of the structural model, indicating that five of the research hypotheses were supported.

The results provide support for $\mathrm{H} 1$ and $\mathrm{H} 3$ that an involvement orientation $(\beta=-.38, p<.01)$ and long-term

Table 3. Correlation Matrix and Descriptive Statistics

\begin{tabular}{|c|c|c|c|c|c|c|c|c|c|}
\hline \multicolumn{2}{|c|}{ Variable $^{\mathrm{a}, \mathrm{b}}$} & \multirow{2}{*}{$\begin{array}{l}1 . \\
.82\end{array}$} & \multirow[t]{2}{*}{2.} & \multirow[t]{2}{*}{3.} & \multirow[t]{2}{*}{4.} & \multirow[t]{2}{*}{5.} & \multirow[t]{2}{*}{6.} & \multirow[t]{2}{*}{7.} & \multirow[t]{2}{*}{8.} \\
\hline 1. & Involvement orientation & & & & & & & & \\
\hline 2. & Involvement depth & .38 & .80 & & & & & & \\
\hline 3. & Long-term commitment & .22 & .08 & .94 & & & & & \\
\hline 4. & Causal ambiguity & -.28 & -.13 & -.22 & .79 & & & & \\
\hline 5. & Project performance & .19 & .15 & .39 & -.20 & .81 & & & \\
\hline 6. & New product advantage & .00 & .10 & .01 & -.16 & .16 & .91 & & \\
\hline 7. & Competitor imitation & .00 & .11 & -.16 & .08 & .01 & .26 & - & \\
\hline \multirow[t]{5}{*}{8.} & Technological newness & -.11 & -.02 & -.08 & .02 & -.10 & .28 & .33 & - \\
\hline & Mean & 4.78 & 5.30 & 5.86 & 3.13 & 4.98 & 5.36 & 2.64 & .60 \\
\hline & Standard deviation & 1.25 & 1.51 & 1.22 & .96 & 1.00 & 1.34 & .90 & .49 \\
\hline & Composite reliability & .83 & .82 & .94 & .85 & .83 & .91 & - & - \\
\hline & Average variance extracted & .56 & .61 & .79 & .55 & .56 & .72 & - & - \\
\hline
\end{tabular}

${ }^{\mathrm{a}}$ For $n=119, r$ has to be .187 or higher to be significant $(p<.05) .{ }^{\mathrm{b}}$ Cronbach's alpha shown on the diagonal. 


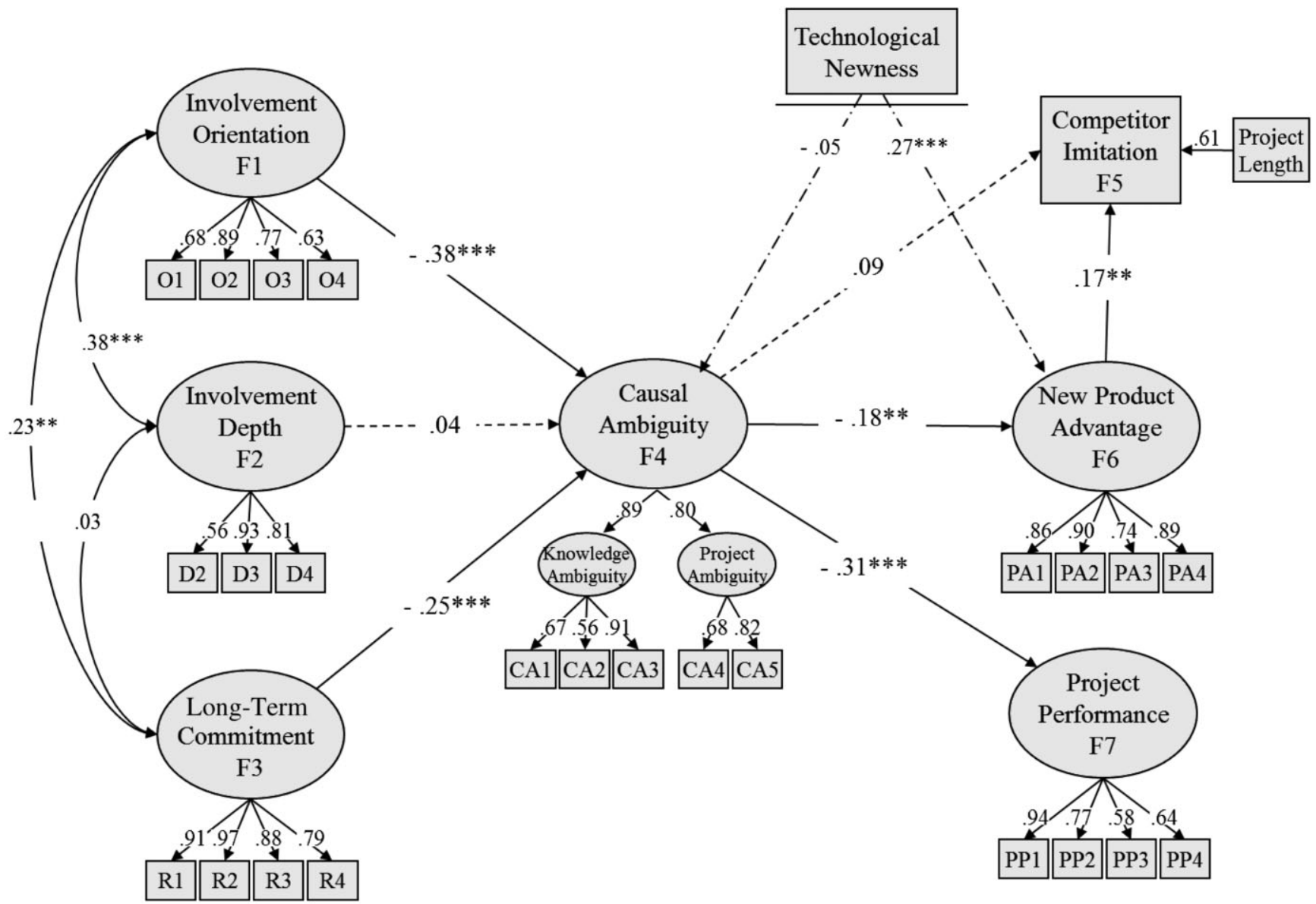

Figure 2. Structural Model.

$* p<.05, * * p<.01, * * * p<.01$ All One-Tailed Tests. Error Terms Are Omitted for Clarity. Nonsignificant Relationships Shown as Dotted Line. $n=119$

commitment $(\beta=-.25, p<.01)$ lower the level of causal ambiguity experienced within the interorganizational NPD team. No significant relationship between involvement depth and causal ambiguity was identified $(\beta=.04$, NS), and thus $\mathrm{H} 2$ was not supported. No significant relationship was found for $\mathrm{H} 4$ between causal ambiguity and competitor imitation $(\beta=.09$, NS). Instead, the results indicate that causal ambiguity has a negative effect on new product advantage $(\beta=-.18, p<.05)(\mathrm{H} 5)$, and in turn, new product advantage delays competitor imitation $(\beta=.17, p<.05)$ (H6). Finally, the results reveal that causal ambiguity decreases project performance $(\beta=-.31, p<.001)$, providing support for $\mathrm{H} 7$.

With regards to control variables, project length (estimated) was significantly related to time to competitor imitation $(\beta=.61, \quad p<.001)$, while technological newness was significantly associated with new product advantage $(\beta=.27, p<.01)$, but not to the level of causal ambiguity experienced within the NPD project.

\section{Discussion}

A theoretical model was developed to explore the relationships among supplier involvement practices, causal ambiguity, and performance within interorganizational NPD teams. The causal ambiguity paradox proposed by King and Zeithaml (2001) was also examined, whereby causal ambiguity contributes differentially to performance outcomes. These relationships are discussed further below.

H1 proposed that firms with a greater orientation toward supplier involvement are more likely to experience a lower prevalence of causal ambiguity in their NPD teams. Given the importance of strategic alignment to interorganizational relationships, it is perhaps not surprising that supplier involvement orientation plays such an important role in interorganizational NPD teams (Ragatz, Handfield, and Petersen, 2002; Spanjol et al., 2011). Benefits range from greater strategic alignment arising from a formal methodology governing the involvement process, 
a shared technology road map, and a behavioral incentive to minimize the introduction of ambiguity into the NPD team. Decision-makers within the NPD team are thus better able to reduce the confusion, complexity, bureaucracy, and ambiguity of interorganizational decisionmaking (Cording et al., 2008). These findings are consistent with previous studies examining the role of strategic orientation and alignment in integrated NPD teams (Spanjol et al., 2011).

$\mathrm{H} 2$ proposed that the more extensively suppliers are involved in the NPD project, the lower the extent of causal ambiguity experienced by the NPD team (Clark and Fujimoto, 1991; Takeishi, 2001). However, contrary to expectations, the results found no significant association between involvement depth and causal ambiguity. Previous research has indicated many benefits from deep integration with suppliers, but it appears that reducing the ambiguity of project knowledge is not among them. For a subset of firms, it is possible that supplier involvement may actually infuse greater complexity, and coordination problems into the NPD project, which, in turn, leads to greater causal ambiguity (Petersen et al., 2005). Alternatively, a curvilinear U-shaped relationship between involvement depth and causal ambiguity may exist, with low or high levels of supplier involvement being associated with greater ambiguity. Mixed results from past studies into the effect of involvement depth also support this conclusion (Hartley, Meredith, McCutcheon, and Kamath, 1997; Primo and Amundson, 2002).

Consistent with relational theory, the results of $\mathrm{H} 3$ indicate that a long-term commitment to the selected supplier is an important antecedent of causal ambiguity reduction. Such relationships minimize the short-term behavioral incentive for suppliers to act opportunistically, allow experience to accumulate between both partners, and facilitate investment in organizational routines which provide longer-term returns (Athaide and Klink, 2009). Firms who adopt a shorter-term horizon to the development relationship are unlikely to find the supplier willing to invest in reducing the causal ambiguity generated by working across organizational boundaries. These findings emphasize to managers the importance of careful supplier selection such that the relational norms and expectations about the future of the relationship are aligned.

The theoretical framework also investigated the causal ambiguity paradox (King and Zeithaml, 2001). $\mathrm{H} 4$ proposed that causal ambiguity would delay the time taken for competitor imitation. No support was found for this assertion. This finding is consistent with recent theoretical contributions (King, 2007) suggesting that the importance placed upon interfirm causal ambi- guity may have been overstated, and that intrafirm causal ambiguity may be a more important determinant of organizational performance (Strang and Still, 2006). The results may also indicate the presence of the competence substitution dilemma identified by McEvily, Das, and McCabe (2000), and Polidoro and Khoon (2011). Ironically, high levels of causal ambiguity may induce competitors to forego imitation and develop alternative means to achieving the technological functionality exhibited by the product, thus negating the advantages of inimitability.

H5 was supported, showing that causal ambiguity in the NPD project decreases the ability of the firm to capture a new product advantage (Atuahene-Gima and Wei, 2011). Results indicate that when product development teams suffer from a high degree of causal ambiguity, they find it difficult to identify which resources determine the performance of the new product, impairing their ability to generate a new product advantage. Causal ambiguity can also limit factor mobility within the collaborative NPD project, and increase the likelihood that quality defects and glitches will be designed into the new product because decision-makers do not know how to identify and solve technological problems (Hoopes and Postrel, 1999; Koufteros et al., 2010; Rauniar et al., 2008).

The results also provide support for H6 that new product advantage helps to delay time to competitor imitation (McEvily and Chakravarthy, 2002). Taken together with the results from $\mathrm{H} 4$, the findings illustrate that it is a firm's new product advantage, rather than the inimitability generated by causal ambiguity, that plays a central role in prolonging imitation by competitors. Interviews with managers from a Tier 1 manufacturer of vehicle sensor equipment further elucidated this result. They observed that in their joint development work with a key component supplier, delaying competitor imitation came from introducing new products which pushed the technological frontier of the prevailing product architecture. High levels of ambiguity served simply to disrupt the orderly development of the product, and limited their understanding of the technological interfaces between the firm and its supplier.

Finally, the results provide support for $\mathrm{H} 7$ that causal ambiguity decreases project performance. In an environment characterized by high causal ambiguity, team members find it difficult to understand the factors which drive key project goals of cost, schedule, and technical objectives (e.g., resolution of technical problems), limiting their ability to develop managerial solutions to poor project performance (Pich et al., 2002; Szulanski, 1996). 
Loch, DeMeyer, and Pich (2006) in their research on novel projects highlight how this uncertainty leads to underestimated project workload, an understaffed team, which when combined with tight deadlines and budget pressures, leads to projects that fail to meet top management's expectations.

\section{Managerial Implications}

A number of implications for managers seeking to involve suppliers in NPD are identified. The article highlights to managers the benefits of adopting supplier involvement practices, such as developing a formal policy for managing supplier involvement and building a longterm commitment, as important prerequisites to building integrated problem-solving cycles and causal ambiguity reduction. In doing so, firms can leverage their supplier involvement efforts in order to jointly solve causally ambiguous technological problems and minimizing ambiguities with the technology, components, processes, and systems used during NPD (Atuahene-Gima and Wei, 2011). However, managers are cautioned that simply involving suppliers early and deeply in NPD does not, of itself, lead to a better understanding of the technological and knowledge interfaces between the firm and its supplier.

The results suggest that a product development strategy based upon maintaining interfirm causal ambiguity to delay competitor imitation is unlikely to result in a sustainable competitive advantage (Ambrosini and Bowman, 2010). Instead, managers are encouraged to undertake initiatives which clarify their understanding of the interactions among project resources and technologies, and in doing so, improve product and project-related performance. Such recommendations echo observations by King (2007, p. 176) who suggests that "decreased levels of causal ambiguity allow organization members to make better decision for their firms."

\section{Limitations and Future Directions}

Whilst the study provides new insights into the management of supplier involvement, a number of limitations are present. First, although the potential confounding effects of variables, such as technological newness, were controlled for, other variables may also impact the constructs of interest. Second, data were collected only from key informants on the buyer's side of the dyad. Although we took steps to identify the most knowledgeable respondent, the possibility of common methods bias does exist.
Third, the cross-sectional nature of the data means inferences cannot be made about how supplier involvement and causal ambiguity evolve over time, and the implications for managing interorganizational NPD teams. Finally, the research setting focuses exclusively on manufacturing firms in the United Kingdom, which potentially limits generalizability.

Despite these limitations, the study does provide a number of future research directions for this area of research. Building on research by Echtelt et al. (2008), in-depth qualitative case study research would help illustrate the dynamics and trade-offs made by NPD team leaders in managing the project, the supplier, and the transfer of technical knowledge. Future research could also explore how causal ambiguity might be minimized through different managerial practices, such as product strategy, cross-functional teams, job rotation, marketingindustrial design integration, product modularity, customer integration, and project management capabilities (Dahl, 2011; Lau et al., 2010; Lau, Yam, and Tang, 2011; Zhang, Hu, and Kotabe, 2011). It would also be interesting to explore how firms build a new product strategy that not only provides the performance benefits from lower causal ambiguity, but also better allows the firm to appropriate the gains from their innovations and delay competitor imitation.

This study examined the performance effects of casually ambiguous knowledge generated during interorganizational NPD projects. Causal ambiguity, operationalized as a second-order factor encompassing both intrasources and intersources of ambiguity, shows that causal ambiguity acts as a powerful block on new product advantage and project performance, but does not provide concomitant benefits of delayed competitor imitation (King and Zeithaml, 2001). Managers are encouraged to adopt practices which limit the extent of causal ambiguity generated by the involvement of parties outside of the firm's boundaries.

\section{References}

Ambrosini, V., and C. Bowman. 2010. The impact of causal ambiguity on competitive advantage and rent appropriation. British Journal of Management 21 (4): 939-53.

Anderson, J. C., and D. W. Gerbing. 1988. Structural equation modeling in practice: A review and recommended two-step approach. Psychological Bulletin 103: 411-23.

Arbuckle, J. L. 2006. Amos user's guide 7.0. Chicago, IL: Amos Development Corporation.

Armstrong, S. J., and T. S. Overton. 1977. Estimating non-response bias in mail surveys. Journal of Marketing Research 14 (3): 396-402.

Athaide, G. A., and R. R. Klink. 2009. Managing seller-buyer relationships during new product development. Journal of Product Innovation Management 26 (5): 566-77. 
Atuahene-Gima, K., and Y. Wei. 2011. The vital role of problem-solving competence new product success. Journal of Product Innovation Management 28 (1): 81-98.

Bagozzi, R. P., and Y. Yi. 1988. On the evaluation of structural models. Journal of the Academy of Marketing Science 16 (1): 74-94.

Barney, J. 1991. Firm resources and sustained competitive advantage. Journal of Management 17 (1): 99-120.

Bonaccorsi, A., and A. Lipparini. 1994. Strategic partnerships in new product development: An Italian case study. Journal of Product Innovation Management 11 (2): 134-45.

Bstieler, L. 2006. Trust formation in collaborative new product development. Journal of Product Innovation Management 23 (1): 56-72.

Bstieler, L., and M. Hemmert. 2010. Increasing learning and time efficiency in interorganizational new product development teams. Journal of Product Innovation Management 27 (4): 485-99.

Chen, I. J., and A. Paulraj. 2004. Towards a theory of supply chain management: The constructs and measurements. Journal of Operations Management 22 (2): 119-50.

Clark, K. B., and T. Fujimoto. 1991. Product development performance. Boston, MA: Harvard Business School Press.

Comer, J. M., and B. J. Zirger. 1997. Building a supplier-customer relationship using joint new product development. Industrial Marketing Management 26: 203-11.

Cording, M., P. Christman, and D. King. 2008. Reducing causal ambiguity in acquisition integration: Intermediate goals as mediators of integration decisions and acquisition performance. Academy of Management Journal 51 (4): 744-67.

Dahl, D. W. 2011. Clarity in defining product design: Inspiring research opportunities for the design process. Journal of Product Innovation Management 28 (3): 425-27.

Dierickx, I., and K. Cool. 1989. Asset stock accumulation and the sustainability of competitive advantage. Management Science 35 (12): 150411 .

Dillman, D. A. 2000. Mail and Internet surveys: The tailored design method (2nd ed.). New York: John Wiley.

Dyer, J. H., and W. G. Ouchi. 1993. Japanese-style partnerships: Giving companies a competitive edge. Sloan Management Review 35 (1): 51-63.

Dyer, J. H., and H. Singh. 1998. The relational view: Cooperative strategy and sources of interorganizational competitive advantage. Academy of Management Review 23 (4): 660-79.

Echtelt, F. E. A., F. Wynstra, A. J. Weele, and G. Duysters. 2008. Managing supplier involvement in new product development: A multiple-case study. Journal of Product Innovation Management 25 (2): 180-201.

Eisenhardt, K. M., and B. N. Tabrizi. 1995. Accelerating adaptive processes: Product innovation in the global computer industry. Administrative Science Quarterly 40: 84-110.

Fornell, C., and D. F. Larcker. 1981. Evaluating structural equation models with unobservable variables and measurement error. Journal of Marketing Research 18 (1): 39-50.

Forza, C. 2002. Survey research in operations management: A processbased perspective. International Journal of Operations \& Production Management 22 (2): 152-94.

Gerbing, D. W., and J. C. Anderson. 1992. Monte Carlo evaluations of goodness of fit indices for structural equation models. Sociological Methods and Research 21 (2): 132-60.

Hair, J. F., R. E. Anderson, R. L. Tatham, and W. C. Black. 1998. Multivariate data analysis (5th ed.). Englewood Cliffs, NJ: Prentice-Hall.

Hartley, J. L., J. R. Meredith, D. McCutcheon, and R. R. Kamath. 1997. Suppliers' contributions to product development: An exploratory study. IEEE Transactions on Engineering Management 44 (3): 258-67.

Hartley, J. L., B. J. Zirger, and R. R. Kamath. 1997. Managing the buyersupplier interface for on-time performance in product development. Journal of Operations Management 15: 57-70.
Henderson, R. M., and K. B. Clark. 1990. Architectural innovation: The reconfiguration of existing product technologies and the failure of established firms. Administrative Science Quarterly 35 (1): 9-31.

Hoopes, D. G., and S. Postrel. 1999. Shared knowledge, "glitches," and product development performance. Strategic Management Journal 20: 837-65.

Huber, G. P. 1991. Organizational learning: The contributing process and the literatures. Organization Science 2: 88-115.

Jayaram, J. 2008. Supplier involvement in new product development projects: Dimensionality and contingency effects. International Journal of Production Research 46 (13): 3717-35.

Johnsen, T. E. 2009. Supplier involvement in new product development and innovation: Taking stock and looking to the future. Journal of Purchasing and Supply Management 15 (3): 187-97.

Jöreskog, K. G., and D. Sörbom. 1993. LISREL 8: Analysis of linear structural relationships by maximum likelihood, instrument variables and least squares methods (8th ed.). Morresville, IN: Scientific Software.

King, A. W. 2007. Disentangling interfirm and intrafirm causal ambiguity: A conceptual model of causal ambiguity and sustainable competitive advantage. Academy of Management Review 32 (1): 156-78.

King, A. W., and C. P. Zeithaml. 2001. Competencies and firm performance: Examining the casual ambiguity paradox. Strategic Management Journal 22: 75-99.

King, B. E., and R. J. Penleskey. 1992. Impediments to timely delivery of new products at an industrial product firm. International Journal of Operations and Production Management 12: 56-65.

Koufteros, X. A., G. E. Rawski, and R. Rupak. 2010. Organizational integration for product development: The effects on glitches, on-time execution of engineering change orders, and market success. Decision Sciences 41 (1): 49-80.

Lau, A. K. W., E. Tang, and R. C. M. Yam. 2010. Effects of supplier and customer integration on product innovation and performance: Empirical evidence in Hong Kong manufacturers. Journal of Product Innovation Management 27 (5): 761-77.

Lau, A. K. W., R. C. M. Yam, and E. Tang. 2011. The impact of product modularity on new product performance: Mediation by product innovativeness. Journal of Product Innovation Management 28 (2): 270-84.

Lawson, B., K. J. Petersen, P. D. Cousins, and R. B. Handfield. 2009. Knowledge sharing in interorganizational product development teams: The effect of formal and informal socialization mechanisms. Journal of Product Innovation Management 26 (2): 156-72.

Lieberman, M. B., and S. Asaba. 2006. Why do firms imitate each other? Academy of Management Review 31: 366-85.

Lieberman, M. B., and D. B. Montgomery. 1988. First-mover advantages. Strategic Management Journal 9 (Special Issue: Strategy Content Research): 41-58.

Liker, J. K., R. R. Kamath, S. N. Wasti, and M. Nagamachi. 1996. Supplier involvement in automotive component design: Are there really large US Japan differences? Research Policy 25: 59-89.

Lippman, S. A., and R. P. Rumelt. 1982. Uncertain imitability: An analysis of interfirm differences in efficiency under competition. Bell Journal of Economics 13: 418-53.

Loch, C. H., A. DeMeyer, and M. T. Pich. 2006. Managing the unknown: A new approach to managing high uncertainty and risks in projects. Hoboken, NJ: John Wiley \& Sons, Inc.

McEvily, S. K., and B. Chakravarthy. 2002. The persistence of knowledgebased advantage: An empirical test for product performance and technological knowledge. Strategic Management Journal 23: 285-305.

McEvily, S. K., S. Das, and K. McCabe. 2000. Avoiding competence substitution through knowledge sharing. Academy of Management Review 25 (2): 294-311.

McNally, R. C., E. Cavusgil, and R. J. Calantone. 2010. Product innovativeness dimensions and their relationships with product advantage, 
product financial performance, and project protocol. Journal of Product Innovation Management 27: 991-1006.

Meyer, C. 1993. Fast cycle time: How to align purpose, strategy and structure for speed. New York: Free Press.

Mosakowski, E. 1997. Strategy making under causal ambiguity: Conceptual issues and empirical evidence. Organization Science 8: 414-42.

Ordanini, A., G. Rubera, and R. DeFillippi. 2008. The many moods of inter-organizational imitation: A critical review. International Journal of Management Reviews 10 (4): 375-98.

Parkhe, A. 1993. Strategic alliance structuring: A game theoretic and transaction cost examination of interfirm cooperation. Academy of Management Journal 36 (4): 794-829.

Paulraj, A., A. A. Lado, and I. J. Chen. 2008. Inter-organizational communication as a relational competency: Antecedents and performance outcomes in collaborative buyer-supplier relationships. Journal of Operations Management 26: 45-64.

Petersen, K. J., R. B. Handfield, and G. L. Ragatz. 2003. A model of supplier integration into new product development. Journal of Product Innovation Management 20 (4): 284-99.

Petersen, K. J., R. B. Handfield, and G. L. Ragatz. 2005. Supplier integration into new product development: Coordinating product, process and supply chain design. Journal of Operations Management 23 (4): 37188 .

Pich, M. T., C. H. Loch, and A. De Meyer. 2002. On uncertainty, ambiguity, and complexity in project management. Management Science 48 (8): 1008-23.

Polidoro, F., Jr., and T. P. Khoon. 2011. Letting rivals come close or warding them off? The effects of substitution threat on imitation deterrence. Academy of Management Journal 54 (2): 369-92.

Powell, T. C., D. Lovallo, and C. Caringal. 2006. Causal ambiguity, management perception, and firm performance. Academy of Management Review 31 (1): 175-96.

Primo, M. A. M., and S. D. Amundson. 2002. An exploratory study of the effects of supplier relationships on new product development outcomes. Journal of Operations Management 20 (1): 33-52.

Ragatz, G. L., R. B. Handfield, and K. J. Petersen. 2002. Benefits associated with supplier integration into new product development under conditions of technology uncertainty. Journal of Business Research 55 (5): 389-400.

Ragatz, G. L., R. B. Handfield, and T. V. Scannell. 1997. Success factors for integrating suppliers into new product development. Journal of Product Innovation Management 14 (3): 190-202.

Rauniar, R., W. J. Doll, G. E. Rawskic, and P. Hong. 2008. Shared knowledge and product design glitches in integrated product development. International Journal of Production Economics 114 (2): 723-36.

Reed, R., and R. J. DeFillippi. 1990. Causal ambiguity, barriers to imitation, and sustainable competitive advantage. Academy of Management Review 15 (1): 88-102.

Rijsdijk, S. A., F. Langerak, and E. J. Hultink. 2011. Understanding a two-sided coin: Antecedents and consequences of a decomposed product advantage. Journal of Product Innovation Management 28 (1): $33-47$.

Sako, M. 1992. Prices, quality and trust: Buyer supplier relationships in Britain and Japan. Cambridge: Cambridge University Press.

Simonin, B. L. 1999. Ambiguity and the process of knowledge transfer in strategic alliances. Strategic Management Journal 20 (7): 595-623.

Song, M., and C. A. Di Benedetto. 2008. Supplier's involvement and success of radical new product development in new ventures. Journal of Operations Management 26 (1): 1-22.

Song, M., and M. M. Montoya-Weiss. 2001. The effect of perceived technological uncertainty on japanese new product development. Academy of Management Journal 44 (1): 61-80.

Song, M., and M. E. Parry. 1997. The determinants of japanese new product successes. Journal of Marketing Research 34 (1): 64-76.
Spanjol, J., W. J. Qualls, and J. A. Rosa. 2011. How many and what kind? The role of strategic orientation in new product ideation. Journal of Product Innovation Management 28 (2): 236-50.

Strang, D., and M. C. Still. 2006. Does ambiguity promote imitation, or hinder it? An empirical study of benchmarking teams. European Management Review 3: 101-12.

Stump, R. L., and J. B. Heide. 1996. Controlling supplier opportunism in industrial relationships. Journal of Marketing Research 33 (4): 431-41.

Szulanski, G. 1996. Exploring internal stickiness: Impediments to the transfer of best practice within the firm. Strategic Management Journal 17 (Special Issue): 27-43.

Takeishi, A. 2001. Bridging inter- and intra-firm boundaries: Management of supplier involvement in automobile product development. Strategic Management Journal 22: 403-33.

von Hippel, E. 1988. The sources of innovation. New York: Oxford University Press.

von Hippel, E. 1994. Sticky information and the locus of problem solving: Implications for innovation. Management Science 40: 429-39.

Wagner, S. M., and M. Hoegl. 2006. Involving suppliers in product development: Insights from R\&D directors and project managers. Industrial Marketing Management 35 (8): 936-43.

Wasti, N. S., and J. K. Liker. 1997. Risky business or competitive power? Supplier involvement in Japanese product design. Journal of Product Innovation Management 14 (5): 337-55.

Wynstra, F., F. von Corswant, and M. Wetzels. 2010. In chains? An empirical study of antecedents of supplier product development activity in the automotive industry. Journal of Product Innovation Management 27 (5): 625-39

Zhang, D., P. Hu, and M. Kotabe. 2011. Marketing-industrial design integration in new product development: The case of China. Journal of Product Innovation Management 28 (3): 360-73.

\section{Appendix. Items and Constructs}

\section{Involvement Orientation}

(O1) We have a formal methodology for involving suppliers in product development

(O2) We involve key suppliers in product development

(O3) There is a strong consensus in our firm that supplier involvement is needed in product development

(O4) Our key suppliers have a major influence on the development of new products

Involvement Depth

(D1) Concept development ${ }^{\mathrm{a}}$

(D2) Product design

(D3) Prototype building and testing

(D4) Preproduction

\section{Long-Term Commitment}

(R1) Our relationship with this supplier is long-term in nature

(R2) We are committed to the preservation of this relationship

\footnotetext{
atem was dropped during scale purification.
} 
(R3) The supplier sees our relationship as a long-term alliance

(R4) We expect to be working with this supplier for the foreseeable future

(R5) Our relationship with this supplier is of very little significance to us (r) ${ }^{\mathrm{a}}$

\section{Causal Ambiguity}

(CA1) The association between inputs and outputs related to the technological know-how held by the supplier was clear ( $r$ )

(CA2) The supplier's technological know-how was easily transferable back to our firm (r)

(CA3) The association between causes and effects related to the technological know-how held by the supplier was clear ( $r$ )

(CA4) Within this project we knew why a given action result in a given outcome (r)

(CA5) It was well known how the different technologies within the project interacted to produce the outcome (r)

(CA6) When a problem surfaced the precise reasons for failure could not be articulated ${ }^{\mathrm{a}}$

\section{Project Performance}

(PP1) meet quality standards

(PP2) meet technical objectives

(PP3) achieve schedule targets

(PP4) achieve project goals

(PP5) budgeted cost targets ${ }^{\mathrm{a}}$
New Product Advantage

(PA1) Offered unique features or attributes to the customer

(PA2) Was clearly superior in terms of meeting customers' needs

(PA3) Offered higher quality-tighter specs, stronger, lasted longer, or more reliable

(PA4) Had superior technical performance

(PA5) Permitted the customer to do a job or do something he could not presently do ${ }^{a}$

\section{Technological Newness}

(NT1) Minor modification (changes were less than 20\%) of a product design already developed at our firm

(NT2) Major modification (20 to 80\%) of a product design already developed at our firm

(NT3) Completely new design (more than $80 \%$ ), but its design was based on a technology that had been demonstrated in another project within our firm

(NT4) This product was technologically new to our company and represented a completely new design

\section{Competitor Imitation}

The time taken (in months) for major competitors to replicate the performance improvements achieved in the firm's new product $(\log )$. 